\title{
Possible mechanism of growth inhibition by Scutellaria baicalensis in an estrogen-responsive mouse tumor cell line
}

\author{
TERUKO MURASHIMA ${ }^{1,2,3}$, HIROSHI KATAYAMA ${ }^{1,2}$, KIMURA SHOJIRO $^{3}$ and YASUKO NISHIZAWA ${ }^{1,2}$ \\ ${ }^{1}$ Department of Pathology, Research Institute, Osaka Medical Center for Cancer and Cardiovascular Diseases, \\ 1-3-3 Nakamichi, Higashinari 537-8511; ${ }^{2}$ Laboratory of Clinical and Experimental Pathophysiology, Graduate \\ School of Pharmaceutical Science, Osaka University, Suita 565-0871; ${ }^{3}$ Department of Radiochemical \\ Laboratory, Osaka University of Pharmaceutical Sciences, Takatsuki 569-1094, Osaka, Japan
}

Received December 15, 2010; Accepted February 2, 2011

DOI: $10.3892 /$ or.2011.1196

\begin{abstract}
We have studied the effects of Saiboku-to, a traditional Chinese medicine having suppressive activities for leukotriene production and release, on the proliferation of the estrogen-responsive mouse Leydig tumor cell line B-1F. In our previous reports, it is shown that Saiboku-to promotes, but Scutellaria baicalensis, one of the components (herbs) of Saiboku-to, significantly inhibits the proliferation of B-1F cells in vitro and in vivo, and induces DNA fragmentation and morphological changes such as nuclear aggregation and fragmentation. In this study, we examined telomerase activity, cell cycle, polyunsaturated fatty acid metabolism and expression of nuclear factor $\kappa \mathrm{B}(\mathrm{NF}-\kappa \mathrm{B})$ in order to determine the mechanism of growth inhibition in $\mathrm{B}-1 \mathrm{~F}$ cells treated with Scutellaria baicalensis. Telomerase activity was decreased in a dose-dependent manner in treated B-1F cells. Cellular populations in the sub-G0/G1 and G2/M phases were increased, but those in M phase had no change. Although cyclin D1 mRNA was highly expressed in the presence of estradiol (E2), cyclin $A$ and E mRNA levels did not significantly change. When B-1F cells were treated with Scutellaria baicalensis, expression of cyclin D1 was suppressed and that of p21 was inversely increased. Moreover, Scutellaria baicalensis influenced arachidonic and linoleic acid metabolism, and increased production of 13(S)-HODE. In the presence of E2 Scutellaria baicalensis decreased expression of NF- $\mathrm{B}$ p65 to 0.71 -fold in B-1F cells. These results show that Scutellaria baicalensis might induce cell cycle arrest at G1 phase and apoptosis via inhibition of telomerase activity, changes of enzymatic activities in polyunsaturated fatty acid metabolism and suppression of NF- $\kappa \mathrm{B}$.
\end{abstract}

Correspondence to: Dr Yasuko Nishizawa, Department of Pathology, Research Institute, Osaka Medical Center for Cancer and Cardiovascular Diseases, 1-3-3 Nakamichi, Higashinari 537-8511; and Laboratory of Clinical and Experimental Pathophysiology, Graduate School of Pharmaceutical Science, Osaka University, Suita 565-0871, Japan

E-mail: nisizawa-ya@mc.pref.osaka.jp

Key words: Scutellaria baicalensis, 13(S)-HODE, apoptosis

\section{Introduction}

Traditional Chinese medicines have been used for treatments of acute and chronic diseases. A traditional Chinese medicine is composed of many components (herbs) and shows various pharmacological actions, mechanisms of which are not fully understood. Also many herbs contained flavonoids which are known to have anti-inflammatory, antioxidant, antibacterial, antiviral and antitumor activities (1-5). Therefore, anti-carcinogenic action and induction of apoptosis by herbs and their constituents are interesting topics of research. In the studies on the effects of Saiboku-to on cell proliferation, we have found that Scutellaria baicalensis, one component of Saiboku-to, suppresses the proliferation of estrogen-responsive mouse tumor cell line B-1F. Scutellaria baicalensis also contains many flavonoids (6). Recent studies suggest that Scutellaria baicalensis effectively arrests cell cycle and induces apoptosis of tumor cell lines $(3,7,8)$.

Telomerase is a ribonucleoprotein (RNP) complex and is composed of telomerase reverse transcriptase (TERT), telomerase RNA component (TERC) and regulating factor of telomerase enzyme activity. Telomerase protects cells from apoptosis by the maintenance of genomic integrity following the stabilization of telomeres (9). Inhibition of telomerase activity has no significant influence on normal cells, but it induces cell death such as apoptosis or senescence in tumor cells.

Arachidonic and linoleic acid metabolites play important roles in carcinogenesis $(10,11)$. When the proliferation of estrogen-responsive B-1F cells is promoted by estradiol (E2), 5-LOX activity is changed and leukotriene (LT) D4 induces apoptosis of B-1F cells (3-9). 13(S)-HODE and 15(S)-HETE (products of 15-LOX-1 and -2, respectively) is known to promote differentiation, growth inhibition and induction of apoptosis. On the other hand, 12(S), 12(R)-HETE, 8(S)-HETE, LTB4 and prostaglandin (PG) E2 (products of 12(S)-LOX, 12(R)-LOX, 8-LOX, 5-LOX and COX-2, respectively) stimulate proliferation, angiogenesis and metastasis.

Nuclear factor $\kappa \mathrm{B}(\mathrm{NF}-\kappa \mathrm{B})$ forms a complex with an inhibitor of $\kappa \mathrm{B}(\mathrm{I} \kappa \mathrm{B})$. I $\kappa \mathrm{B}$ bound to $\mathrm{NF}-\kappa \mathrm{B}$ dissociates from the complex by phosphorylation, and $\mathrm{NF}-\kappa \mathrm{B}$ stimulates gene transcription by binding to DNA. It has been reported that some constituents of traditional Chinese medicines inhibit NF- $\mathrm{NB}$ and $\mathrm{COX}-2$ 
(12). Flavonoids contain many antioxidants and are related to inhibition of NF- $\mathrm{NB}$ and COX-2 activity by decreasing oxidative stress (12). In this study, we examined telomerase activity, cell cycle, polyunsaturated fatty acid metabolism and expression of NF- $\mathrm{BB}$ in order to clarify the mechanism of growth inhibition in B-1F cells treated with Scutellaria baicalensis.

\section{Materials and methods}

Preparation of extracts from Scutellaria baicalensis and its constituents. The powder of Scutellaria baicalensis was suspended in phosphate-buffered saline (PBS) at a concentration of $20 \mathrm{mg} / \mathrm{ml}$ (wt of the powder/solvent volume). The suspension was sonicated and centrifuged. Then the supernatant was collected. The powder of each constituent of Scutellaria baicalensis was dissolved in ethanol to $1 \mathrm{mg} / \mathrm{ml}$ except Saikosaponin d $(0.1 \mathrm{mg} / \mathrm{ml})$. The solution was stored at $4^{\circ} \mathrm{C}$ in dark until use.

Cell culture. B-1F cells were maintained in Eagle's minimum essential medium-Ham's F12 (1:1, vol/vol) containing $0.1 \%$ (wt/vol) bovine serum albumin (BSA) (HMB medium) and $10^{-8} \mathrm{M}$ E2 (HMBE medium). Cells were grown and passaged, as previously described (13).

In vitro cell growth experiments. Cells were treated with various concentrations of Scutellaria baicalensis and its constituents. Cell growth experiments were carried out as previously published $(13,14)$.

Immunohistochemistry for cleaved caspase-3. B-1F cells were seeded in four well chamber slides (Falcon) at a density of $2 \times 10^{4}$ cells/well in HMB medium. The following day (day $0)$, the medium was changed to fresh HMBE medium with $2.5 \mu \mathrm{g} / \mathrm{ml}$ of each constituent of Scutellaria baicalensis. Cleaved caspase-3 was detected by immunohistochemistry as described in our previous report (13).

Telomerase activity. Telomerase activity was examined using TRAPeze telomerase detection kit (S7700) as directed in the manual from the supplier. Briefly, B-1F cells were seeded at a density of $2.5 \times 10^{5}$ cells $/ 100-\mathrm{mm}$ dish in HMB medium. The following day (day 0 ), the medium was changed to HMB or HMBE medium with or without $25 \mu \mathrm{g} / \mathrm{ml}$ of Scutellaria baicalensis. On day 2 or 3 , floating and attached cells were collected together, the cell pellets $\left(\sim 10^{6}\right.$ cells $)$ were resuspended in $200 \mu \mathrm{l}$ of CHAPS Lysis Buffer containing $5 \mu \mathrm{l}$ RNase inhibitor and their protein concentrations were determined. Equivalent amounts of protein $(0.552 \mu \mathrm{g})$ were mixed with TRAP reaction mixture and incubated for $30 \mathrm{~min}$ at $30^{\circ} \mathrm{C}$. As a negative control, every sample extract was heated by incubating at $85^{\circ} \mathrm{C}$ for $10 \mathrm{~min}$ in order to inactivate telomerase. Following procedures are described in the manual. Amplified products were subjected to electrophoresis on $2 \%$ agarose gel containing ethidium bromide and visualized under UV light.

Cell cycle analysis. B-1F cells were seeded at a density of $2.5 \times 10^{6}$ cells $/ 100-\mathrm{mm}$ dish in HMB medium. The following day (day 0), the medium was changed to HMB or HMBE medium with or without 25 or $50 \mu \mathrm{g} / \mathrm{ml}$ of Scutellaria baicalensis. On day 1 or 2, floating and attached cells were collected together, resuspended in PBS and fixed overnight in $70 \%$ ethanol at $4^{\circ} \mathrm{C}$. The cells were washed with PBS, resuspended in $40 \mu \mathrm{l}$ of the buffer $\left(0.2 \mathrm{M} \mathrm{Na}_{2} \mathrm{HPO}_{4}, 0.1 \mathrm{M}\right.$ citric acid, $\left.\mathrm{pH} 7.0\right)$ and incubated for $30 \mathrm{~min}$. After washed, the cells in $100 \mu \mathrm{l}$ of PBS were incubated with RNase inhibitor at $37^{\circ} \mathrm{C}$ for $30 \mathrm{~min}$, washed and resuspended in $1 \mathrm{ml}$ of PBS containing $50 \mu \mathrm{l} /$ $\mathrm{ml}$ of propidium iodide, followed by incubation in the dark for $30 \mathrm{~min}$ at room temperature. Thereafter, cell cycle was analyzed by a FACScan flow cytometer (Becton Dickinson, Franklin Lakes, NJ, USA).

We examined expression of cyclin and CDK inhibitors in B-1F cells treated with or without $50 \mu \mathrm{g} / \mathrm{ml}$ of Scutellaria baicalensis. The method for RNA isolation was the same as previously published (14). RT-PCR was performed as directed in the manual from the supplier (Ready-To-Go ${ }^{\mathrm{TM}} \mathrm{RT}-\mathrm{PCR}$ Beads). First strand cDNA was synthesized at $42^{\circ} \mathrm{C}$ for $30 \mathrm{~min}$ using $1 \mu \mathrm{g}$ of total RNA and specific primers. PCR conditions for cyclin A were $95^{\circ} \mathrm{C}$ for $30 \mathrm{sec}, 56^{\circ} \mathrm{C}$ for $1 \mathrm{~min}$ and $72^{\circ} \mathrm{C}$ for $2 \mathrm{~min}$ for 30 cycles, for cyclin D1 were $94^{\circ} \mathrm{C}$ for $1 \mathrm{~min}$, $60^{\circ} \mathrm{C}$ for $1 \mathrm{~min}$ and $72^{\circ} \mathrm{C}$ for $2 \mathrm{~min}$ for 40 cycles, for cyclin $\mathrm{E}$ were $94^{\circ} \mathrm{C}$ for $45 \mathrm{sec}, 58^{\circ} \mathrm{C}$ for $45 \mathrm{sec}$ and $72^{\circ} \mathrm{C}$ for $90 \mathrm{sec}$ for 30 cycles, for p21 were $94^{\circ} \mathrm{C}$ for $45 \mathrm{sec}, 62^{\circ} \mathrm{C}$ for $45 \mathrm{sec}$ and $72^{\circ} \mathrm{C}$ for $1 \mathrm{~min}$ for 27 cycles and for GAPDH were $94^{\circ} \mathrm{C}$ for $45 \mathrm{sec}, 55^{\circ} \mathrm{C}$ for 45 seconds and $72^{\circ} \mathrm{C}$ for 2 min for 35 cycles. After PCR amplification, all products were incubated for $10 \mathrm{~min}$ at $72^{\circ} \mathrm{C}$. Amplified products were separated on $2 \%$ agarose gel containing ethidium bromide and visualized under UV light. Mouse cyclin A primers are 5'-CACTCACAC ACTTAGTGTCTCTGGTGGG-3' (forward) and 5'-GCCGC GATGCCGGGCACCTCGAGGCATTCG-3' (reverse), and RT-PCR product is 1277 bp. Mouse cyclin D1 primers are 5'-CGCCTTCCGTTTCTTACTTCA-3' (forward) and 5'-AAC TTCTCGGCAGTCAGGGGA-3' (reverse), and RT-PCR product is $250 \mathrm{bp}$. Mouse cyclin E primers are 5'-CTGGCTGA ATGTTTATGTCC-3' (forward) and 5'-TCTTTGCTTGGG CTTTGTCC-3' (reverse), and RT-PCR product is $386 \mathrm{bp}$. Mouse p21 primers are 5'-AGCCTGAAGACTGTGATGGG-3' (forward) and 5'-AAAGTTCCACCGTTCTCGG-3' (reverse), and RT-PCR product is $228 \mathrm{bp}$. Mouse GAPDH primers are 5'-ATCTTCCAGGAGCGAGACCCCA-3' (forward) and 5'-TCCACAATGCCAAAGTTGTCATGG-3' (reverse), and RT-PCR product is $289 \mathrm{bp}$.

Assay of polyunsaturated acid metabolites and enzymatic activities. Assays of arachidonic acid metabolites and enzymatic activities were carried out as previously reported $(15,16)$. The level of 13(S)-HODE was measured by 13(S)HODE enzyme immunoassay kit. B-1F cells were seeded at a density of $0.5-1 \times 10^{6}$ cells $/ 60-\mathrm{mm}$ dish in $\mathrm{HMB}$ medium. The following day (day 0), the medium was changed to HMB or HMBE medium with or without $50 \mu \mathrm{g} / \mathrm{ml}$ of Scutellaria baicalensis. On day 2, the medium was replaced with fresh medium containing the same compounds and the cells were incubated for $7 \mathrm{~h}$. After incubation, the cells and medium were collected. The cells were washed with PBS, scraped into lysis buffer (10 mM Tris-HCl, pH 7.4, $400 \mathrm{mM} \mathrm{NaCl}, 1 \mathrm{mM}$ EDTA, $1.0 \% \mathrm{SDS}$ ) and incubated for $15 \mathrm{~min}$ at $4^{\circ} \mathrm{C}$. Cell lysates were centrifuged at $15000 \mathrm{xg}$ for $15 \mathrm{~min}$ at $4^{\circ} \mathrm{C}$. The 


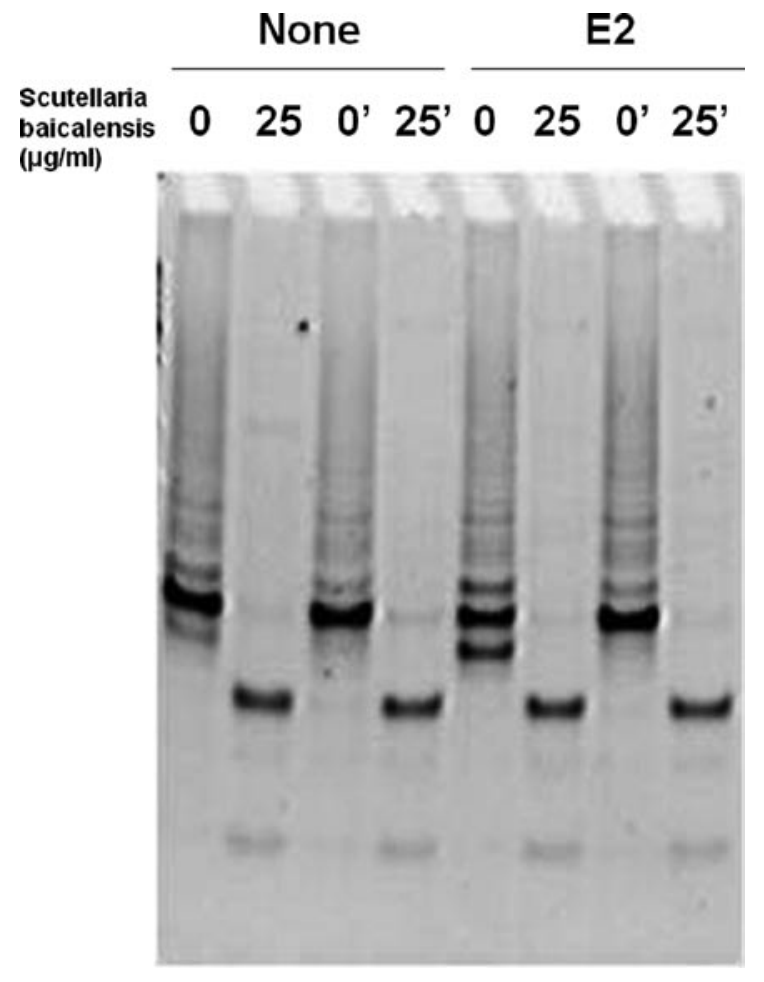

Figure 1. Telomerase activity in B-1F cells. B-1F cells were seeded onto $100-\mathrm{mm}$ dishes $\left(2.5 \times 10^{5}\right.$ cells/dish) and treated with or without $25 \mu \mathrm{g} / \mathrm{ml}$ of Scutellaria baicalensis in the presence (E2) or absence (none) of E2. Telomerase activity was examined using TRAPeze telomerase detection kit (S7700). Amplified products were subjected to electrophoresis on $2 \%$ agarose gel containing ethidium bromide and visualized under UV light. Lanes with concentration of Scutellaria baicalensis + ['] are heat-inactivated samples. The other three separate trials gave similar results.

supernatants and the medium were acidified to $\mathrm{pH} 3.5-4.0$ with $0.2 \mathrm{~N} \mathrm{HCl}$. The samples were added a 3 -fold excess of saturated ethyl acetate and shaked to mix. After centrifuged at $82 \times \mathrm{g}$ for $5 \mathrm{~min}$ at $4^{\circ} \mathrm{C}$, the upper layer (organic phase) was collected into a fresh tube. These extraction steps were repeated (a total of three times). Collected organic phases were dried completely, dissolved in $25 \mu \mathrm{l}$ of ethanol and diluted with Assay Buffer so that alcohol content in the sample was below $20 \%$. The enzyme immunoassay for 13(S)-HODE was performed as directed in the manual from the supplier.

Expression of $N F-\kappa B$. Total RNA from B-1F cells treated with $25 \mu \mathrm{g} / \mathrm{ml}$ of Scutellaria baicalensis for 2 days was prepared using the TRIzol reagent as previously described. RNA $(2 \mu \mathrm{g})$ was reversely transcribed using Ready-To-Go RT-PCR Beads and oligo pd(N)6 primers. Real-time PCR was carried out using POWER SYBR-Green PCR Master Mix and gene-specific primers (ABI 7500 instrument, Applied Biosystems). Primers for mouse NF- $\kappa$ B, p65, are 5'-CAAGATCAATGGCTACACAGGACC-3' and 5'-GCAGATCTTGAGCTCGGCAGTG-3'. Primers for mouse $\beta$-actin were in real-time PCR kit. Briefly, approximately $25 \mu \mathrm{l}$ of reaction volume was consisted of $2 \mathrm{X}$ SYBR-Green PCR Master Mix (12.5 $\mu$ l), NF-kB p65 Pre-mixed Primer set $(5 \mu \mathrm{l})$ or $10 \mathrm{x} \beta$-actin primer set $(2.5 \mu \mathrm{l})$, and suitable quantity of distilled water. The PCR profile was 1 cycle at $50^{\circ} \mathrm{C}$ for
2 min and at $95^{\circ} \mathrm{C}$ for $10 \mathrm{~min}, 40$ cycles at $95^{\circ} \mathrm{C}$ for $15 \mathrm{sec}$ and at $60^{\circ} \mathrm{C}$ for $1 \mathrm{~min}$, and $1 \mathrm{cycle}$ at $95^{\circ} \mathrm{C}$ for $15 \mathrm{sec}$, at $60^{\circ} \mathrm{C}$ for $1 \mathrm{~min}$ and at $95^{\circ} \mathrm{C}$ for $15 \mathrm{sec}$. The data were analyzed using ABI 7500 software.

Analysis of estrogen binding sites. The whole cell binding assay was used to study the binding parameters of estrogen binding sites in B-1F cells as previously published (1). Briefly, B-1F cells $\left(2 \times 10^{6}\right.$ cells) were incubated with $5 \mathrm{nM}\left[2,4,6,7-{ }^{3} \mathrm{H}(\mathrm{N})\right]$ estradiol $\left(\left[{ }^{3} \mathrm{H}\right] \mathrm{E} 2\right)$ in the presence of various concentrations of major constituents of Scutellaria baicalensis for $60 \mathrm{~min}$ at $37^{\circ} \mathrm{C}$. The cells washed with ice-cold HMB medium were transferred to scintillation vials for the determination of the radioactivity specifically bound to the cells.

Materials. The materials were purchased as described previously $(13,14)$. TRAPeze telomerase detection kit was purchased from Chemicon International (CA, USA); 13(S)HODE enzyme immunoassay kit from Assay Designs, Inc. (MI, USA); Mouse NF- $\mathrm{kB}$ factor, p65, Primer set kit and realtime PCR kit for mouse $\beta$-actin gene expression from Maxim Biotech. Inc. (San Francisco, USA); Power SYBR-Green PCR master mix from Applied Biosystems (UK); propidium iodide and powder forms of constituents of Scutellaria baicalensis from WAKO (Osaka, Japan).

Statistics. The data were expressed as the mean \pm standard error (SE). Data were analyzed by ANOVA with Dunnett's or Bonferroni's corrections for multiple comparisons, as appropriate. Calculated p-values of $<0.05$ were considered to be significant.

\section{Results}

Suppression of telomerase activity in B-1F cells by Scutellaria baicalensis. Effects of Scutellaria baicalensis on telomerase activity are shown in Fig. 1. Although we examined telomerase activity on days 2 and 3, only results on day 2 are shown, because similar results were obtained on both days. When B-1F cells were treated with Scutellaria baicalensis, telomerase activity was inhibited under both conditions with and without E2.

Cell cycle arrest of $B-1 F$ cells by Scutellaria baicalensis. After the treatment with 25 or $50 \mu \mathrm{g} / \mathrm{ml}$ Scutellaria baicalensis, cell cycle was analyzed by flow cytometry on day 1 . The result is shown in Fig. 2A. Scutellaria baicalensis increased cellular populations in sub-G0/G1 phase and G2/M phase. As shown in Fig. 2B, cyclin A and E mRNA did not significantly change with the treatment. In contrast, cyclin D1 mRNA was expressed in the presence of E2, but when B-1F cells were treated with Scutellaria baicalensis, it was suppressed. Expression of p21, CDK inhibitor, was increased. These results show that Scutellaria baicalensis might arrest cell cycle at G1 phase by changing the expression of cyclin D1 and p21.

Effects of Scutellaria baicalensis on polyunsaturated acid metabolism in B-1F cells. B-1F cell proliferation stimulated by E2 is concurrent with decreased 5-LOX activity and then decreased production of LT. At first, we examined effects of 
A

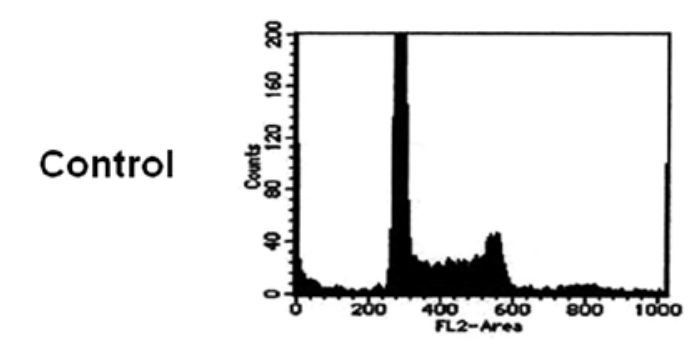

$25 \mu \mathrm{g} / \mathrm{ml}$
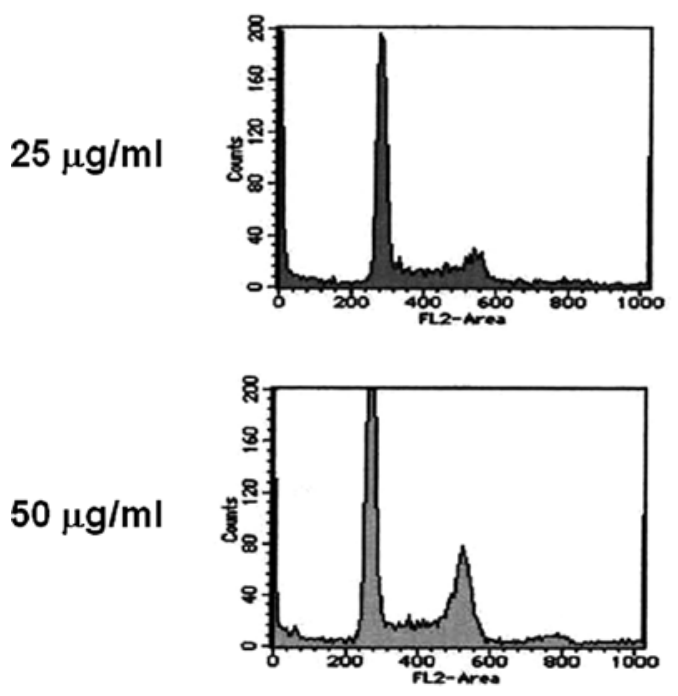

E2
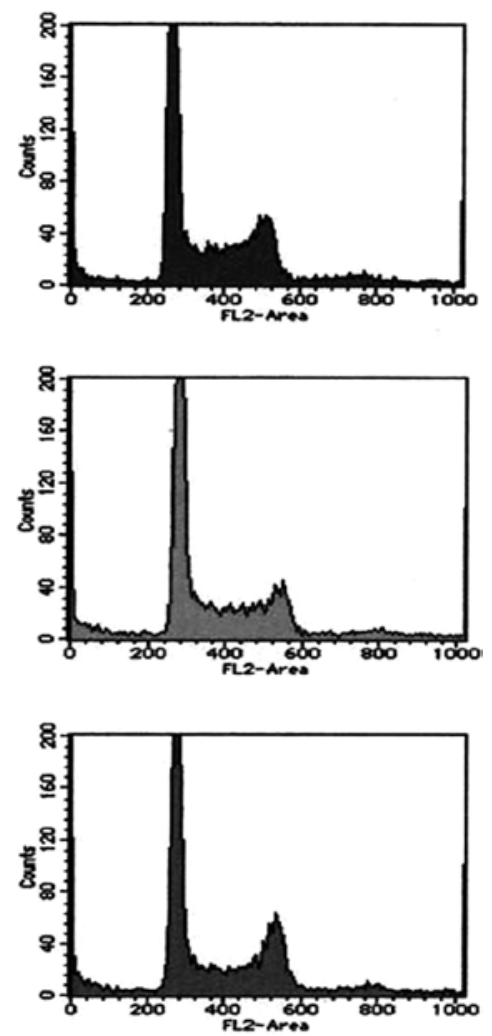

B

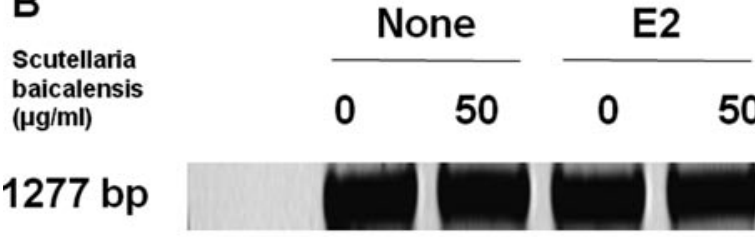

Cyclin A

$250 \mathrm{bp}$

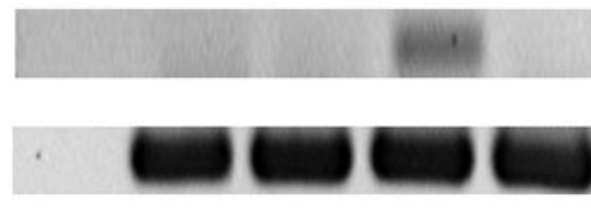

Cyclin D1

$386 \mathrm{bp}$

\section{Cyclin E}

$228 \mathrm{bp}$

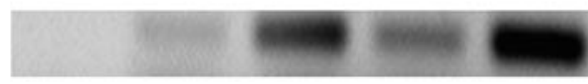

p21

$346 \mathrm{bp}$

GAPDH

Figure 2. Cell cycle analysis by flow cytometry and expression of cyclin A, D1, E and p21. (A) B-1F cells were seeded at a density of $2.5 \times 10^{6}$ cells/100-mm dish and treated with 25 or $50 \mu \mathrm{g} / \mathrm{ml}$ of Scutellaria baicalensis in the presence (E2) or absence (none) of E2. Cell cycle was analyzed by flow cytometry using propidium iodide staining. (B) B-1F cells were seeded onto $100-\mathrm{mm}$ dishes $\left(2 \times 10^{6}\right.$ cells/dish) and treated with $50 \mu \mathrm{g} / \mathrm{ml}$ of Scutellaria baicalensis. On day 3 , total RNA was extracted and expression of several genes related to cell cycle was determined by RT-PCR as described in Materials and methods. Amplified products were separated on $2 \%$ agarose gel. The other two separate trials gave similar results.

Scutellaria baicalensis on arachidonic acid metabolism in B-1F cells. The results are shown in Fig. 3A and B. Although, activities of 5-LOX and 12-LOX decreased, those of COX-1 and COX-2 increased. 15-LOX activity did not change. Activities of COX-1 and COX-2 increased $~ 2$-fold and 12-LOX activity decreased to $>20 \%$ in B-1F cells treated with Scutellaria baicalensis. In the treated cells and their conditioned medium, 5-HETE and 12-HETE decreased. In contrast PGD2 and PGE2 increased, and 15-HETE did not significantly change.
Next, we examined 13(S)-HODE production (final product from linoleic acid by $15-\mathrm{LOX}-1$ ), in B-1F cells using enzyme immunoassay kit. As shown in Fig. 4, in both cellular fraction and the medium 13(S)-HODE increased (2-fold increase), when the cells were treated with Scutellaria baicalensis.

Expression of $N F-\kappa B$ p65 in B-1F cells treated with Scutellaria baicalensis. NF- $\kappa \mathrm{B}$ is a well-known transcription factor to play important roles in immune response and carcinogenesis 
A
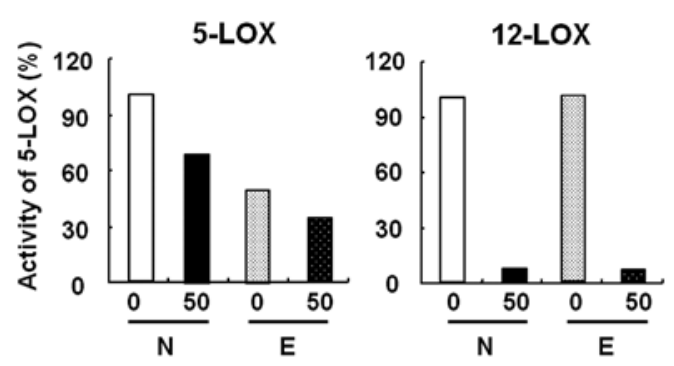

15-LOX
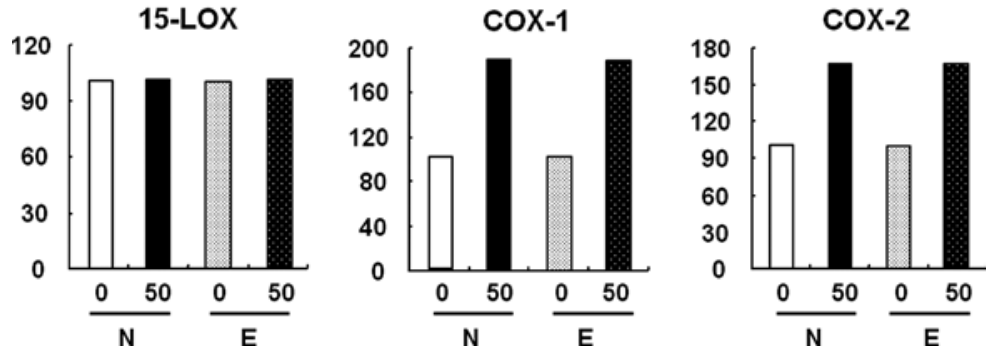

B
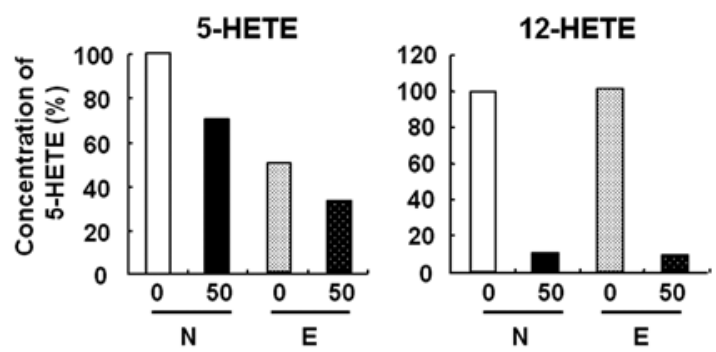

15-HETE
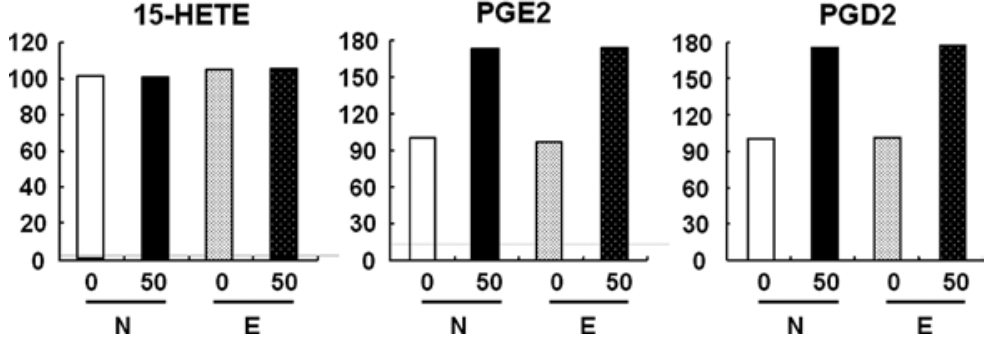

Figure 3. Production of arachidonic acid metabolites and enzymatic activities. Assay of arachidonic acid metabolites was carried out as previously described. The cells were seeded onto $60-\mathrm{mm}$ dishes and treated with $50 \mu \mathrm{g} / \mathrm{ml}$ of Scutellaria baicalensis in the presence (E) or absence (N) of E2. (A) Enzymatic activities (\%) in arachidonic acid metabolism of B-1F cells, (B) concentrations (\%) of arachidonic acid metabolites in treated B-1F cells. Values are means of experiments performed in duplicate and are given as a percentage of the concentration without Scutellaria baicalensis and E2. The other three separate trials gave similar results.

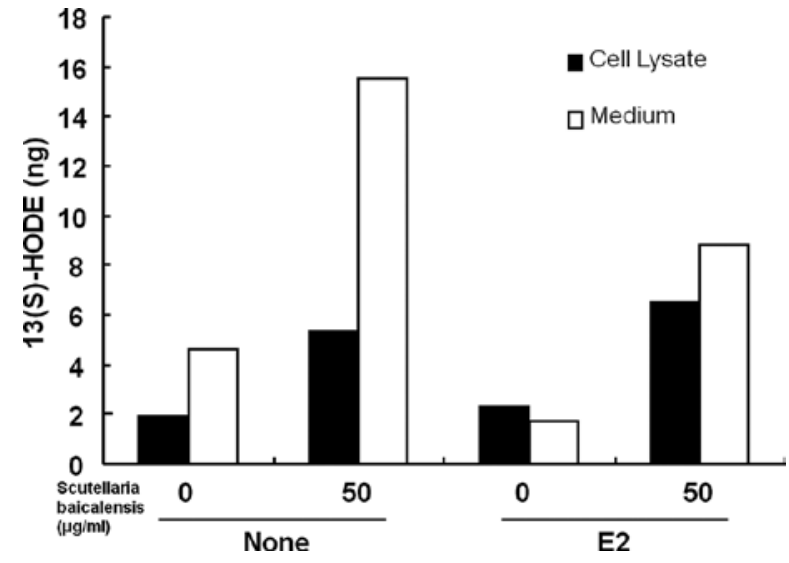

Figure 4. Production of 13(S)-HODE. B-1F cells were seeded onto 60-mm dishes and treated with $50 \mu \mathrm{g} / \mathrm{ml}$ of Scutellaria baicalensis in the presence (E2) or absence (none) of E2 as described in Materials and methods. Assay of 13(S)-HODE was carried out using 13(S)-HODE enzyme immunoassay kit. Values are means of experiments performed in duplicate. The other three separate trials gave similar results.
(17-19). We examined the expression of NF-кB p65 mRNA in B-1F cells treated with Scutellaria baicalensis (Fig. 5). Scutellaria baicalensis decreased NF- $\kappa \mathrm{B}$ p65 expression to 0.71 -fold in the presence of E2.

Effects of major constituents of Scutellaria baicalensis on $B-1 F$ cells. Effects of baicalin, baicalein and wogonin, major constituents of Scutellaria baicalensis, on the cell proliferation are shown in Fig. 6. Wogonin effectively inhibited B-1F cell proliferation in the absence of E2. Baicalein showed twophase effects. Low dose $(0.1-1.0 \mu \mathrm{g} / \mathrm{ml})$ of baicalein increased the proliferation, but higher dose of baicalein inhibited. The most potent growth inhibition was observed in B-1F cells treated with wogonin.

Each constituent of Scutellaria baicalensis did not compete with E2 for estrogen receptor-binding in B-1F cells (Fig. 7), showing that the above constituents do not act directly via estrogen binding sites in B-1F cells, as well as Saiboku-to 


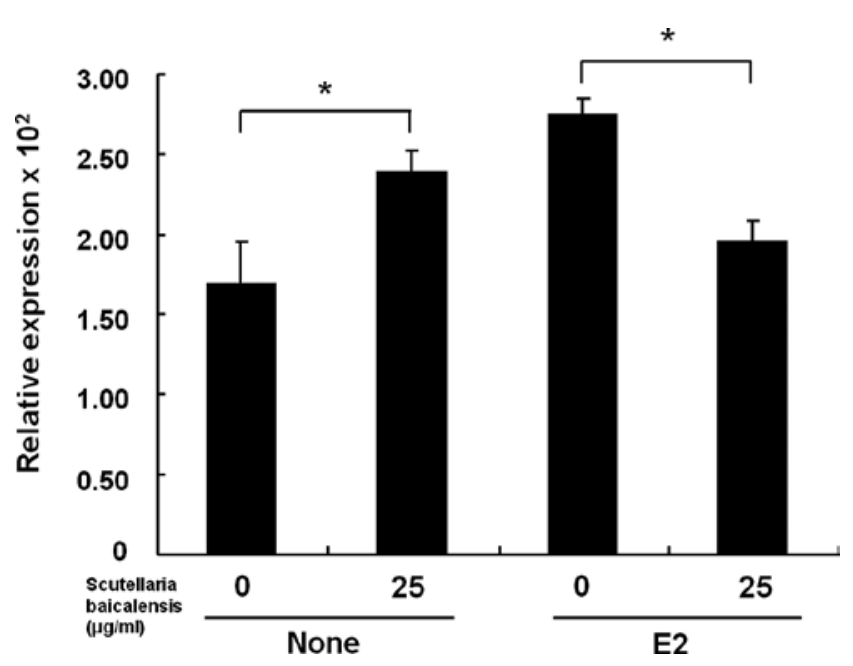

Figure 5. Expression of NF- $\mathrm{KB}$ mRNA in B-1F cells treated with Scutellaria baicalensis. B-1F cells were treated with $25 \mu \mathrm{g} / \mathrm{ml}$ of Scutellaria baicalensis for 2 days in the presence (E2) or absence (none) of E2. Real-time PCR for NF- $\kappa B$ was performed with SYBR-Green system (ABI 7500 instrument). Results are expressed as NF- $\mathrm{KB}$ p65/ $\beta$-actin ratio of the samples. Values are means $\pm \mathrm{SE}$ of three experiments performed in duplicate. ${ }^{*} \mathrm{P}<0.05$ vs. corresponding value without Scutellaria baicalensis.

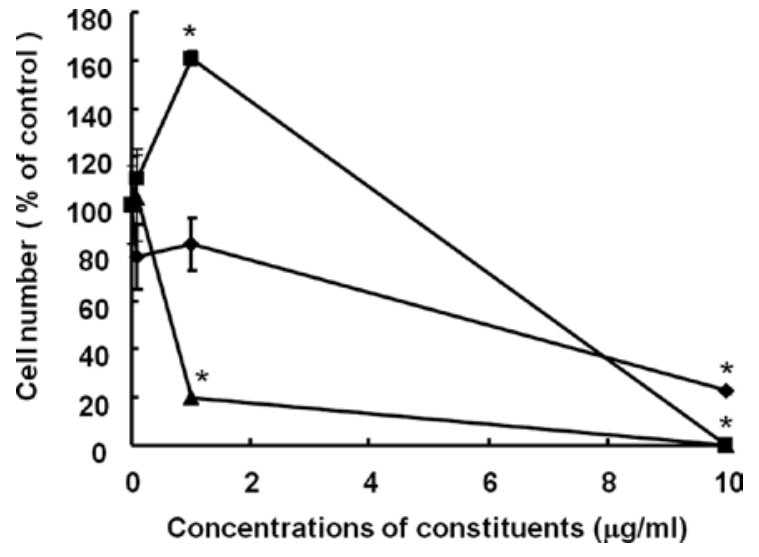

Figure 6. Effects of major constituents of Scutellaria baicalensis on B-1F cell proliferation. B-1F cells were seeded onto $35-\mathrm{mm}$ dishes $\left(3 \times 10^{4}\right.$ cells/ dish) and treated with $0.1,1$ or $10 \mu \mathrm{g} / \mathrm{ml}$ of major constituents of Scutellaria baicalensis for 6 days. The cultured medium was changed with the fresh medium containing test compounds every other day. The proliferation was estimated by counting the number of viable cells. Results are means of four determinations. Bars, SE. The values are given as a percentage of the number per dish without test compound. $\bullet$ baicalin; $\mathbf{\square}$, baicalein; $\boldsymbol{\Lambda}$ wogonin. ${ }^{*} \mathrm{P}<0.05$ vs. corresponding value without constituents. The other three separate trials also gave similar results.
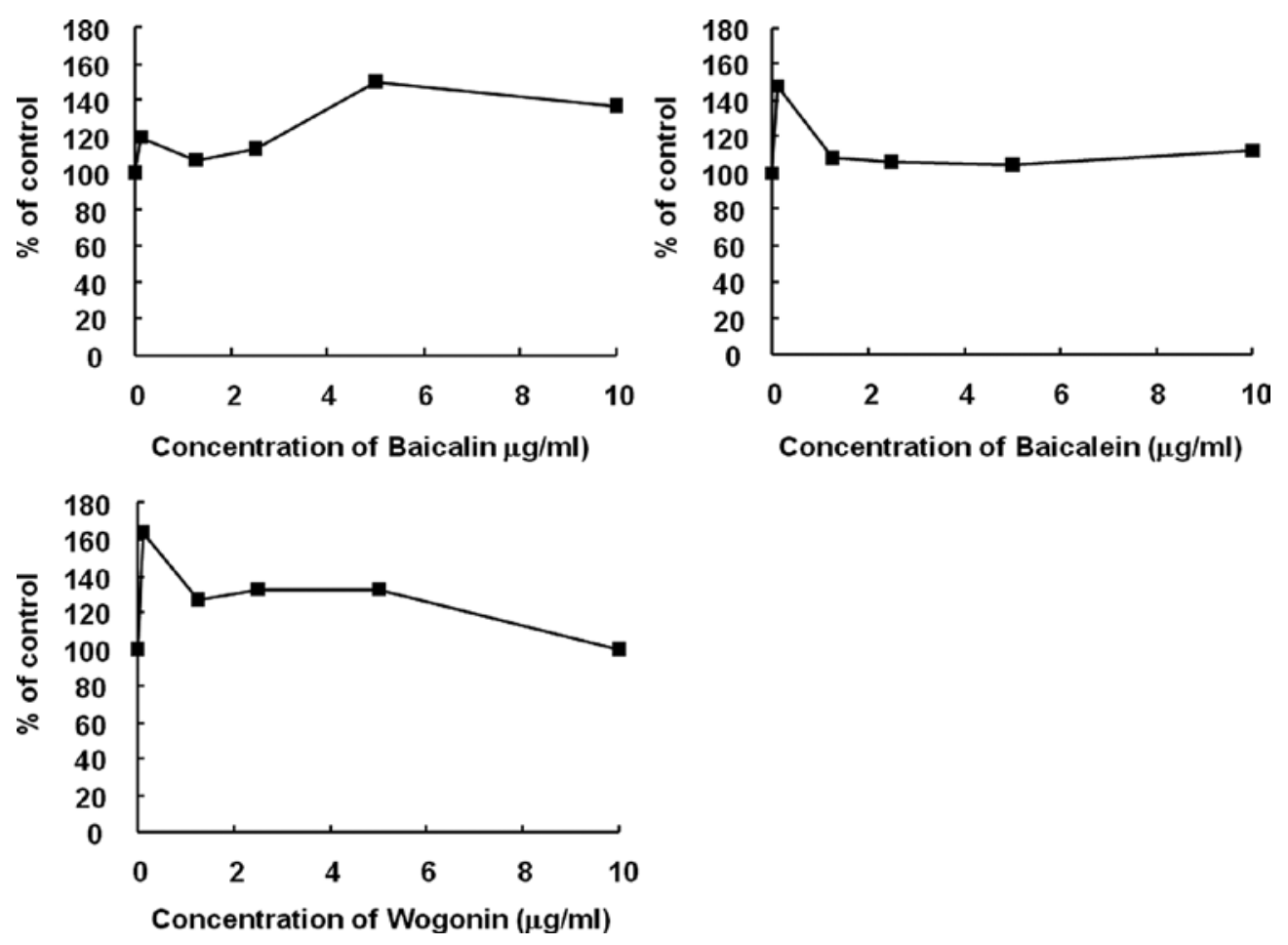

Figure 7. Effects of major constituents of Scutellaria baicalensis on the binding of estrogen to its binding sites. $\left[{ }^{3} \mathrm{H}\right] \mathrm{E} 2$-estrogen binding assays were carried out as described in Materials and methods. The radioactivity binding to washed cells was determined. Values are the means of experiments performed in duplicate and are given as a percentage of the radioactivity per tube without test compound. The other two separate trials also gave similar results.

and Scutellaria baicalensis. When the expression of cleaved caspase-3, using immunohistochemistry, was examined in B-1F cells treated with $2.5 \mu \mathrm{g} / \mathrm{ml}$ of each constituent (Fig. 8), it was increased by the above constituents (the most prominent in wogonin-treated cells). These results indicate that some of constituents induce apoptosis in B-1F cells.

\section{Discussion}

We have demonstrated that Scutellaria baicalensis induces cell cycle arrest and apoptosis in B-1F cells. Telomerase is necessary to maintain cell proliferation and is important for tumorigenesis $(9,20,21)$. Its inhibition leads to suppressive 


\section{None}

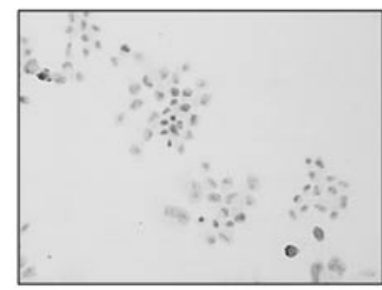

E2

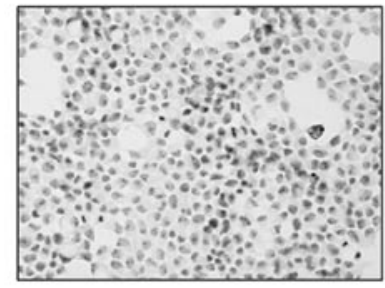

Baicalin

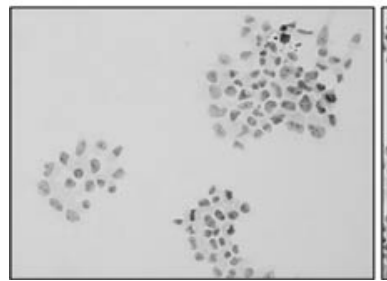

Baicalein

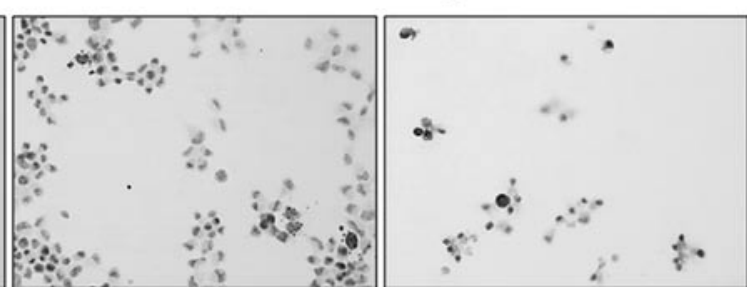

Figure 8. Immunohistochemistry for cleaved caspase-3. The cells were seeded onto four chamber slides and treated with major constituents of Scutellaria baicalensis. On day 3, caspase activation in the treated cells was studied by immunohistochemistry for cleaved caspase-3. The other three separate trials also gave similar results.

cell proliferation, damage of chromosome and apoptosis by up-regulation of p16, p53, p73 and p63 in addition to FasL, Fas, caspase-8, -7 and -3 (22). Further, a cyclin-dependent kinase inhibitor p21 and p53 are closely linked to cell cycle and up-regulation of $\mathrm{p} 21$ is caused by inhibition of telomerase activity (22). In B-1F cells treated with Scutellaria baicalensis telomerase activity was suppressed and cell cycle was arrested at G1 phase with up-regulation of p21 and down-regulation of cyclin D1. One possible explanation for induction of apoptosis and cell cycle arrest in treated B-1F cells is inhibition of telomerase activity.

In order to understand the relationship between polyunsaturated fatty acid metabolism and carcinogenesis, we have investigated mechanism of estrogen-responsive B-1F cell proliferation and have reported that B-1F cell growth stimulated by E2 is concurrent with decreased LT production as a result of decreased 5-LOX activity (14-16,23-26). Treatment with Scutellaria baicalensis inhibited some enzymatic activities in arachidonic acid metabolism (5-LOX and 12-LOX). Baicalein, one of constituents in Scutellaria baicalensis, is known as a 12-LOX inhibitor. On the other hand COX-1 and COX-2 activities increased 2-fold. Among arachidonic acid metabolites production of 5-HETE and 12-HETE was inhibited, but that of PGD2 and PGE2 was increased. The production of an arachidonic acid metabolite 15-HETE, a product of 15-LOX-2, did not change, but a linoleic acid metabolite 13(S)-HODE, a product of 15-LOX-1, was increased by the treatment. Although 15-LOX activity examined by incubation with arachidonic acid showed no significant change, and 15-LOX-1 activity was not directly measured in this report, increment of 15-LOX-1 activity could be estimated from increased 13(S)-HODE production in $\mathrm{B}-1 \mathrm{~F}$ cells. Since 13(S)-HODE is known to promote differentiation, growth inhibition and apoptosis induction, 13(S)-HODE also plays an important role in the inhibition of proliferation of B-1F cells treated with Scutellaria baicalensis.
$\mathrm{NF}-\kappa \mathrm{B}$ forms a complex with an inhibitor of $\kappa \mathrm{B}(\mathrm{I} \kappa \mathrm{B})$ and is located in cytoplasm when it is under inactive conditions. I $\kappa \mathrm{B}$ bound to $\mathrm{NF}-\kappa \mathrm{B}$ dissociates from the complex by phosphorylation following influences of drug, oxidative stress and so on. Then $\mathrm{NF}-\kappa \mathrm{B}$ moves into nucleus and stimulates gene transcription by binding to DNA. NF- $\kappa \mathrm{B}$ regulates expression of many genes (for example, I $\mathrm{B}-\alpha$, bcl-2, IL- 6 and cyclin D1). Suppression of NF- $\kappa$ B activation is known as a key to induction of apoptosis in many cell lines $(3,12,17,27,28)$. In our experiments Scutellaria baicalensis slightly inhibited expression of NF- $\mathrm{B}$ p 65 in B-1F cells in the presence of E2. Moreover, Scutellaria baicalensis contains many flavonoids and its major constituents are baicalin, baicalein, wogonin, neowogonin and skullcapflavone (6). Baicalein and wogonin inhibited B-1F cell proliferation and induced apoptosis. Scutellaria baicalensis and baicalein have been reported to induce apoptosis by blocking I $\kappa \mathrm{B}-\alpha$ phosphorylation (3). Although $\mathrm{NF}-\kappa \mathrm{B}$ expression alone was examined in this study, similar mechanism probably work in B-1F cells. In this study Scutellaria baicalensis increased NF- $\mathrm{NB}$ expression in the absence of E2, by a mechanism which remains unknown.

In conclusion, we have shown that Scutellaria baicalensis induces cell cycle arrest and apoptosis via inhibition of telomerase activity, down-regulation of $\mathrm{NF}-\kappa \mathrm{B}$, and changes of enzymatic activities in polyunsaturated fatty acid metabolism. Scutellaria baicalensis or its constituents might be candidates for the treatment of cancer. For example, they possibly target the restoration of 15-LOX-1 activity for the treatment of colorectal cancer. Shureiqi et al have reported that the loss of 15-LOX-1 expression is the possible dominant change in LOX metabolism during colorectal tumorigenesis (29). Further study is necessary to make clear the roles of Scutellaria baicalensis and its constituents in cancer therapy, and also those of other constituents of Saiboku-to such as Saikosaponin. 


\section{Acknowledgments}

The technical assistance of Mrs. Y. Saeki and Y. Tanigaki is gratefully acknowledged.

\section{References}

1. Kim HP, Son KH, Chang HW and Kang SS: Anti-inflammatory plant flavonoids and cellular action mechanisms. J Pharmacol Sci 96: 229-245, 2004.

2. Li QB, You Y, Chen ZC, Lu J, Shao J and Zou P: Role of Baicalein in the regulation of proliferation and apoptosis in human myeloma RPMI8226 cells. Chin Med J 119: 948-952, 2006.

3. Ma Z, Otsuyama K, Liu S, et al: Baicalein, a component of Scutellaria radix from Huang-Lian-Jie-Du-Tang (HLJDT), leads to suppression of proliferation and induction of apoptosis in human myeloma cells. Blood 105: 3312-3318, 2005.

4. Nakagawa N, Katoh M, Yoshioka Y, Nakajima M and Yokoi T: Inhibitory effects of Kampo medicine on human UGT2B7 activity. Drug Metab Pharmacokinet 24: 490-499, 2009.

5. Takegawa Y, Ikushima H, Ozaki K, et al: Can Kampo therapy prolong the life of cancer patients? J Med Invest 55: 99-105, 2008.

6. Zuo F, Zhou ZM and Liu ML: Determination of 14 chemical constituents in the traditional Chinese medicinal preparation Huangqin-Tang by high performance liquid chromatography. Biol Pharm Bull 24: 693-697, 2001.

7. Scheck AC, Perry K, Hank NC and Clark WD: Anticancer activity of extracts derived from the mature roots of Scutellaria baicalensis on human malignant brain tumor cells. BMC Complement Altern Med 6: 27, 2006.

8. Shih HC, Hsu CS and Yang LL: In vitro study of the tocolytic effect of oroxylin A from Scutellaria baicalensis root. J Biomed Sci 16: 27, 2009.

9. Sung YH, Choi YS, Cheong C and Lee HW: The pleiotropy of telomerase against cell death. Mol Cells 19: 303-309, 2005.

10. Hong SH, Avis I, Vos MD, Martinez A, Treston AM and Mulshine JL: Relationship of arachidonic acid metabolizing enzyme expression in epithelial cancer cell lines to the growth effect of selective biochemical inhibitors. Cancer Res 59: 2223-2228, 1999.

11. Shureiqi I and Lippman SM: Lipoxygenase modulation to reverse carcinogenesis. Cancer Res 61: 6307-6312, 2001.

12. Shukla S and Gupta S: Suppression of constitutive and tumor necrosis factor alpha-induced nuclear factor (NF)-kappaB activation and induction of apoptosis by apigenin in human prostate carcinoma PC-3 cells: correlation with down-regulation of NF-kappaB-responsive genes. Clin Cancer Res 10: 3169-3178, 2004.

13. Murashima T, Yamasaki M, Nishizawa Y, et al: Proliferation of estrogen-responsive mouse tumor cell line B-1F stimulated by Saiboku-to, but inhibited by Scutellaria baicalensis, a component of Saiboku-to. Oncol Rep 22: 257-264, 2009.

14. Goto HG, Nishizawa Y, Katayama H, et al: Induction of apoptosis in an estrogen-responsive mouse Leydig tumor cell by leukotriene. Oncol Rep 17: 225-232, 2007.
15. Nishii K, Nishizawa Y, Nishizawa Y, Matsumoto K and Sato B: Inhibition of murine transformed Leydig cell proliferation by leukotrienes in serum-free culture. Cancer Res 51: 5573-5578, 1991.

16. Nishizawa Y, Nishii K, Nishizawa Y, et al: Effects of estrogen on cell proliferation and leukotriene formation in transformed mouse Leydig cells cultured under serum-free conditions. Cancer Res 50: 3866-3871, 1990.

17. Kishida Y, Yoshikawa $\mathrm{H}$ and Myoui A: Parthenolide, a natural inhibitor of nuclear factor-kappaB, inhibits lung colonization of murine osteosarcoma cells. Clin Cancer Res 13: 59-67, 2007.

18. Li X, Xing D, Wang J, et al: Effects of IkappaBalpha and its mutants on NF-kappaB and p53 signaling pathways. World J Gastroenterol 12: 6658-6664, 2006.

19. Salazar-Montes A, Ruiz-Corro L, Sandoval-Rodriguez A, Lopez-Reyes A and Armendariz-Borunda J: Increased DNA binding activity of NF-kappaB, STAT-3, SMAD3 and AP-1 in acutely damaged liver. World J Gastroenterol 12: 5995-6001, 2006.

20. Murillo-Ortiz B, Astudillo-De la Vega H, Castillo-Medina S, Malacara JM and Benitez-Bribiesca L: Telomerase activity, estrogen receptors (alpha, beta), Bcl-2 expression in human breast cancer and treatment response. BMC Cancer 6: 206, 2006.

21. Saito K, Yagihashi A, Nasu S, et al: Gene expression for suppressors of telomerase activity (telomeric-repeat binding factors) in breast cancer. Jpn J Cancer Res 93: 253-258, 2002.

22. Shammas MA, Koley H, Batchu RB, et al: Telomerase inhibition by siRNA causes senescence and apoptosis in Barrett's adenocarcinoma cells: mechanism and therapeutic potential. Mol Cancer 4: 24, 2005.

23. Nishizawa $Y$, Nishii K, Kishimoto S, Matsumoto K and Sato B: Regulatory role of arachidonic acid-derived metabolites for proliferation of transformed murine Leydig cell in serum-free culture condition. Anticancer Res 10: 317-322, 1990.

24. Nishizawa Y, Nishizawa Y, Yamamoto T, et al: Progression of mouse transformed Leydig cells from estrogen-sensitive to estrogen-insensitive growth phenotype concomitant with loss of leukotriene D4 receptor. Int J Oncol 5: 1077-1084, 1994.

25. Nishizawa Y, Yamamoto T, Taniguchi H and Sato B: Effects of estrogen and leukotrienes on anchorage-independent growth of transformed mouse Leydig cells under serum-free condition. Steroid Biochem (Life Sci Adv) 11: 23-28, 1992.

26. Nishizawa Y, Yamamoto T, Terada N, Fushiki S, Amakata Y and Nishizawa Y: Effects of antiallergic drugs on the proliferation of estrogen-sensitive mouse Leydig cell line. Anticancer Res 16: 1241-1245, 1996.

27. Kim JY, Ahn MH, Jun HS, Jung JW, Ryu JS and Min DY: Toxoplasma gondii inhibits apoptosis in infected cells by caspase inactivation and NF-kappaB activation. Yonsei Med J 47: 862-869, 2006

28. Kuhnel F, Zender L, Paul Y, et al: NFkappaB mediates apoptosis through transcriptional activation of Fas (CD95) in adenoviral hepatitis. J Biol Chem 275: 6421-6427, 2000.

29. Shureiqi I, Wu Y, Chen D, et al: The critical role of 15-lipoxygenase-1 in colorectal epithelial cell terminal differentiation and tumorigenesis. Cancer Res 65: 11486-11492, 2005. 